OPEN

SUBJECT AREAS:

STEM CELLS

BIOLOGICAL MODELS

REPRODUCTIVE BIOLOGY

MEDICAL RESEARCH

Received

12 April 2012

Accepted

16 May 2012

Published

27 July 2012

Correspondence and requests for materials should be addressed to H.M. (moriguchi-tky@ umin.ac.jp)

\section{Successful cryopreservation of human ovarian cortex tissues using supercooling}

\author{
Hisashi Moriguchi ${ }^{1,2}$, Yue Zhang ${ }^{3}$, Makoto Mihara' \& Chifumi Sato ${ }^{4}$
}

'Division of iPS Cell Research and Application, Department of Plastic and Reconstructive Surgery, School of Medicine, The University of Tokyo, Tokyo, Japan, ${ }^{2}$ Massachusetts General Hospital and Harvard Medical School, Boston, USA, ${ }^{3}$ Department of Radiation Oncology, Beth Israel Deaconess Medical Center and Harvard Medical School, USA, ${ }^{4}$ Department of Analytical Health Science, Graduate School of Health Care Sciences, Tokyo Medical and Dental University, Tokyo, Japan.

The development of new method to cryopreserve human ovarian cortex tissues without damage is needed for the improvement of quality of life (QOL) of female cancer patients. Here we show novel cryopreservation method of human ovarian cortex tissues by using supercooling (S.C.) procedure. Our method will be helpful in order to preserve fertility of female cancer patients.

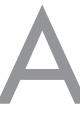

new technology to cryopreserve human ovarian cortex tissues more stably is needed in order to preserve fertility of female cancer patients.

The supercooling phenomenon is a state in which even when the temperature falls below the freezing point, phase conversion from liquid to solid does not occur, though we must note that the supercooling state is eliminated by an external impact (Supplementary video). When frozen instantly from a supercooled state facilitated by a variable magnetic field, freeze concentration is prevented and cell destruction is inhibited ${ }^{1}$.

Therefore, we investigated the efficacy for the cryopreservation of human ovarian cortex tissues by using the supercooling technology.

\section{Results}

The morphology for human oocytes within human ovarian cortex tissues. The typical morphology for human oocytes within human ovarian cortex tissues after supercooling (S.C.) procedure was shown (Figure 1). The morphology was normal.

The expression analyses of human oocyte marker genes for human oocytes within human ovarian cortex tissues between the conventional method (Control) and S.C. procedure. The expressions of widely accepted human oocyte marker genes ${ }^{2}$ for human oocytes within human ovarian cortex tissues according to the method of White YA, et al. ${ }^{2}$ were also maintained higher in S.C. procedure than Control $^{3}$ (Figure 2).

Immunofluorescence analyses for DDX4, KIT, YBX2 and LHX8 expression in oocytes within human ovarian cortex tissues. Immunofluorescence analyses for DDX4, KIT, YBX2 and LHX8 expression in oocytes within human ovarian cortex tissues after S.C. procedure were shown (Figure 3). The each expression for DDX4, KIT, YBX2 and LHX8 was normal.

\section{Discussion}

Our experimental results show that cryopreservation of the human oocytes depends on the success of cryopreservation of the human ovarian cortex tissues by using the S.C. procedure.

The exact influence of supercooling under magnetic field on human cells and/or tissues is unknown. However, we postulate that the destruction of human cells and/or tissues is inhibited, as ice-crystal formation of water molecules within human cells and/or tissues is inhibited during cryopreservation in the magnetic environment.

On the other hand, recently, new germline stem cells that are capable of forming oocytes from human ovaries have been identified ${ }^{2}$. However, the expansion of stem cells in culture almost always leads to the accumulation of potentially harmful mutations ${ }^{4}$. Therefore, the development of new method in order to cryopreserve human oocytes-producing stem cells (OSCs) without damage is needed. However, as the human OSCs are within human ovary cortex tissues ${ }^{2}$, our novel technology by using the S.C. procedure will be also helpful for the successful cryopreservation of human OSCs. 


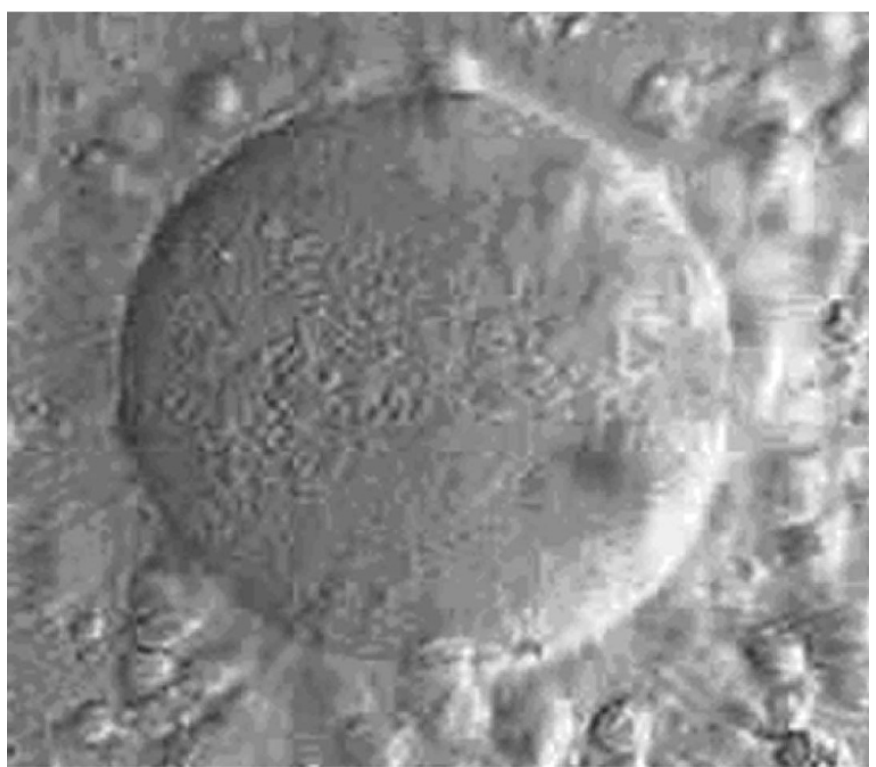

Figure $1 \mid$ The morphology for human oocytes within human ovarian cortex tissues.

In conclusion, our novel technology by using the S.C. procedure is very helpful in order to improve fertility of female cancer patients.

\section{Methods}

Human sample. Human ovarian tissues were surgically removed from a female patient with cervical cancer before chemotherapy and/or radiation therapy in order to preserve her fertility.

The method and/or the procedure of the cryopreservation of human sample. Human ovarian tissues were frozen and thawed by using the conventional method (Control) (Ref. No. 3) or supercooling (S.C.) procedure. The S.C. procedure was as follows. The human ovary was rapidly transported to the laboratory in Leibovitz L-15 medium (Life Technologies, Merelbeke, Belgium). The human ovarian cortex was carefully dissected to obtain 40 small pieces $(10 \times 10 \mathrm{~mm})$, which were then incubated for $30 \mathrm{~min}$ in a cryoprotective solution (Leibovitz medium supplemented with $1.5 \mathrm{M}$ dimethylsulphoxide, $0.1 \mathrm{M}$ sucrose, both provided by Sigma Aldrich, Bornem, Belgium and $10 \%$ patient's serum at $4.0^{\circ} \mathrm{C}$ ). Each piece of the human ovarian cortex was cryopreserved in one 2-ml vial (Simport, Merck Eurolab, Leuven, Belgium), containing $1.4 \mathrm{ml}$ of the cryoprotectant solution. The cryopreservation procedure as S.C. procedure was performed using our supercooling machine (Supplementary Figure 1). The following procedures were used: started at $4.0^{\circ} \mathrm{C}$ $1.0^{\circ} \mathrm{C} / \mathrm{min}$ to $-5.0^{\circ} \mathrm{C}, 20 \mathrm{~min}$ of soaking in a supercooled state under a variable magnetic field $(2 \mathrm{kHz}, 0.3 \mathrm{mT})$, then manual seeding, $1.0^{\circ} \mathrm{C} / \mathrm{min}$ to $-40.0^{\circ} \mathrm{C}$, $10.0^{\circ} \mathrm{C} / \mathrm{min}$ to $-140.0^{\circ} \mathrm{C}$ and then plunged into liquid nitrogen. The pieces of the human ovarian tissue were thawed on the day of the experimental procedure following a rapid protocol: vials were placed at room temperature for $2 \mathrm{~min}$ and then in water at $25.0^{\circ} \mathrm{C}$ for $2 \mathrm{~min}$. The human ovarian tissue was washed stepwise for 5 min each in progressively lower concentrations of the cryoprotectant solution $(1.5,1,0.5$ and $0 \mathrm{~mol} / \mathrm{l})$

Gene expression profiles of human oocytes within human ovarian cortex tissues. The expressions of widely accepted human oocyte marker genes ${ }^{2}$ for human oocytes within human ovarian cortex tissues were investigated. The presence of each indicated mRNA was assessed in total RNA samples by conventional RT-PCR using a SuperScript ${ }^{\circledR}$ VILO $^{\mathrm{TM}}$ cDNA Synthesis Kit (Invitrogen) and Platinum Taq polymerase (Invitrogen). Details for PCR primers used to analyze gene expression in total RNA samples prepared from human cells and tissues were according to the method of White YA, et al. (Ref. No. 2).

Immunoanalysis. For assessment of human oocytes expression of DDX4, KIT, YBX2 and LHX8 within human ovarian cortex tissues, human ovarian cortex tissue was fixed in 4\% PFA, paraffin-embedded and sectioned (6- $\mu \mathrm{m})$ prior to high temperature antigen retrieval using $0.01 \mathrm{M}$ sodium citrate buffer ( $\mathrm{pH} 6.0$ ). After cooling, sections were washed and blocked for $1 \mathrm{~h}$ at $20^{\circ} \mathrm{C}$ using TNK buffer (0.1 M Tris- $\mathrm{HCl}, 0.55 \mathrm{M} \mathrm{NaCl}, 0.1 \mathrm{mM} \mathrm{KCl}, 0.5 \% \mathrm{BSA}$, and $0.1 \%$ Triton-X100 in PBS) containing either $1 \%$ normal goat serum (for subsequent detection of DDX4$\mathrm{COOH}$ in human ovary, YBX2 and LHX8 in human ovary) or 1\% normal donkey serum (DDX4-NH2 in human ovary and KIT in human ovary). Sections were then incubated with a 1:100 dilution of primary antibody (in TNK buffer with $1 \%$

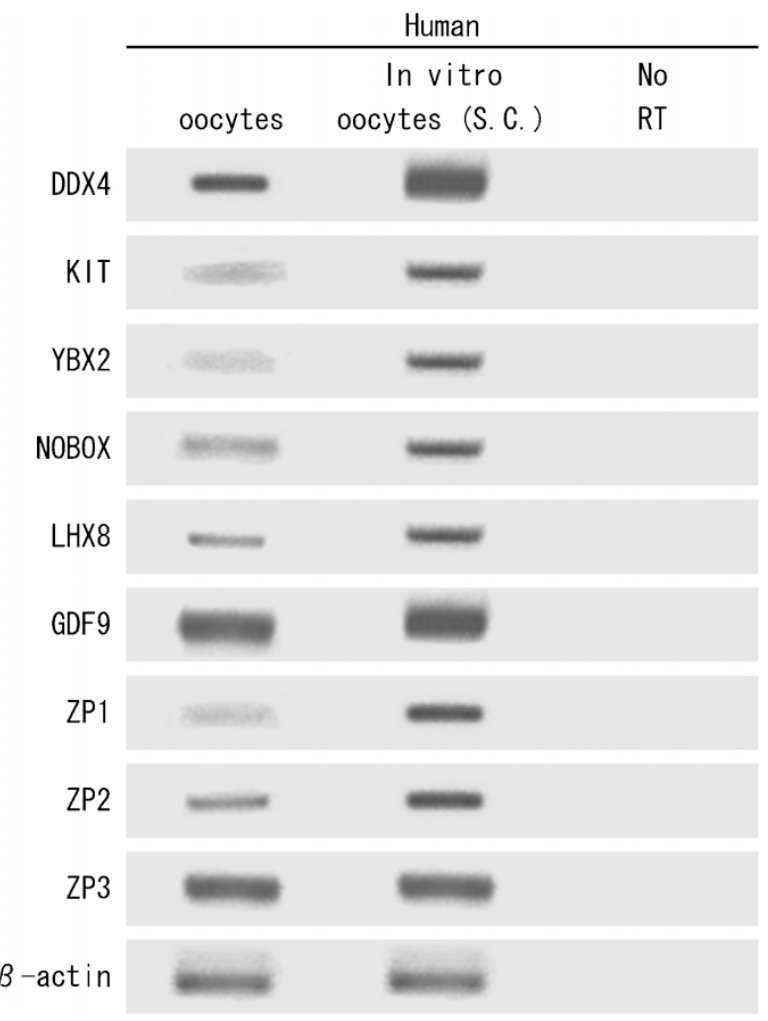

Figure $2 \mid$ The expression analyses of human oocyte marker genes for human oocytes within human ovarian cortex tissues between the conventional method (left: Control) and supercooling (S.C.) procedure (right).

normal serum) overnight at $4{ }^{\circ} \mathrm{C}$ washed in PBS, and incubated for $30 \mathrm{~min}$ at $20^{\circ} \mathrm{C}$ with a 1:500 dilution of goat anti-rabbit IgG conjugated to Alexa Fluor 568 (DDX4-COOH detection in human ovary), goat anti-rabbit IgG conjugated to Alexa Fluor 488 (LHX8 detection in human ovary) or donkey anti-goat IgG conjugated to Alexa Fluor 488 (DDX4-NH2 detection in human ovary and KIT detection in human ovary). For assessment of YBX2 expression in human ovary,

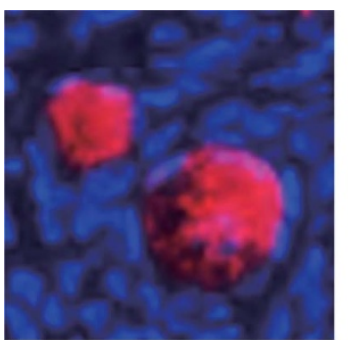

DDX4

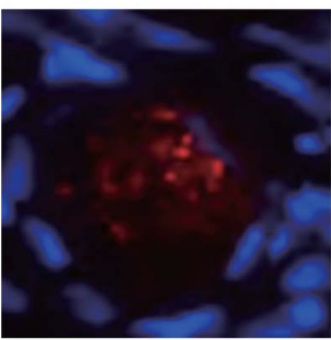

YBX2

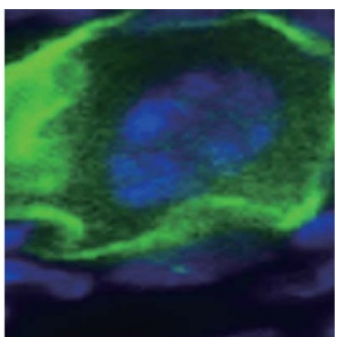

KIT

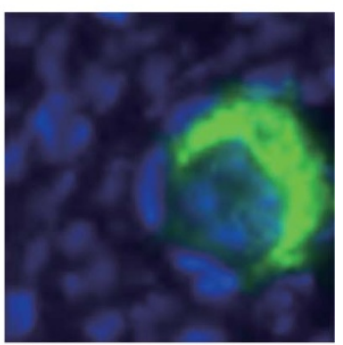

LHX8
Figure 3 Immunofluorescence analyses for DDX4 (red), KIT (green), YBX2 (red) and LHX8 (green) expression in oocytes within human ovarian cortex tissues. Sections were counterstained with DAPI (blue) for visualization of nuclei. 
primary antibody was detected using a goat anti-rabbit biotinylated IgG for $1 \mathrm{~h}$ at $20^{\circ} \mathrm{C}$, followed by reaction with streptavidin-conjugated Alexa Fluor 568. After washing with PBS, sections were cover-slipped using Vectashield containing DAPI (Vector Labs).

A statement identifying the institutional and/or licensing committee experimental approval. The study was approved by the Institutional Review Boards of our institutions (Harvard Medical School, the University of Tokyo), and informed written consent was obtained from the patient.

1. Kaku,M. et al. Cryopreservation of periodontal ligament cells with magnetic field for tooth banking. Cryobiology 61, 73-78 (2010).

2. White, Y. A., Woods, D. C., Takai, Y., Ishihara, O., Seki, H. \& Tilly, J. L. Oocyte formation by mitotically active germ cells purified from ovaries of reproductiveage women. Nat. Med 18, 413-421 (2012).

3. Demeestere, I. et al. Ovarian function and spontaneous pregnancy after combined heterotopic and orthotopic cryopreserved ovarian tissue transplantation in a patient previously treated with bone marrow transplantation: case report. Hum. Reprod. 21, 2010-2014 (2006).

4. International Stem Cell Initiative. Screening ethnically diverse human embryonic stem cells identifies a chromosome 20 minimal amplicon conferring growth advantage. Nat Biotechnol 29, 1132-1144 (2011).

\section{Acknowledgements}

We are grateful to Dr. Ramond T. Chung (Massachusetts General Hospital and Harvard Medical School, USA), Ms. Satoko Iioka, Ms. Midori Okabe and Mr. Akira Fujimoto.

\section{Author contributions}

H.M.: Conception and design, provision of study material, collection and/or assembly of data, data analysis and interpretation, manuscript writing, and final approval of manuscript; C.S., Y.Z. and M.M: provision of study material, collection and/or assembly of data, data analysis and interpretation, manuscript assessment, and final approval of manuscript.

\section{Additional information}

Supplementary information accompanies this paper at http://www.nature.com/ scientificreports

Competing financial interests: The authors declare no competing financial interests.

License: This work is licensed under a Creative Commons

Attribution-NonCommercial-ShareAlike 3.0 Unported License. To view a copy of this license, visit http://creativecommons.org/licenses/by-nc-sa/3.0/

How to cite this article: Moriguchi, H., Zhang, Y., Mihara, M. \& Sato, C. Successful cryopreservation of human ovarian cortex tissues using supercooling. Sci. Rep. 2, 537; DOI:10.1038/srep00537 (2012) 
SUBJECT TERMS: BIOLOGICAL MODELS

STEM CELLS

REPRODUCTIVE BIOLOGY MEDICAL RESEARCH

SCIENTIFIC REPORTS:

$2: 537$

DOI: 10.1038/srep00537

(2012)

Published:

27 July 2012

Updated:

18 October 2012
ADDENDUM: Successful cryopreservation of human ovarian cortex tissues using supercooling

Hisashi Moriguchi, Yue Zhang, Makoto Mihara \& Chifumi Sato

Editorial Note: Successful cryopreservation of human ovarian cortex tissues using supercooling

Scientific Reports has become aware of irregularities related to authors affiliations and the statement describing IRB approval in this paper. The situation is being investigated. 
SUBJECT TERMS: BIOLOGICAL MODELS

STEM CELLS

REPRODUCTIVE BIOLOGY MEDICAL RESEARCH

\section{SCIENTIFIC REPORTS:}

$2: 537$

DOI: $10.1038 /$ srep00537

(2012)

Published:

27 July 2012

Retracted:

9 November 2012
RETRACTION: Successful cryopreservation of human ovarian cortex tissues using supercooling

Hisashi Moriguchi, Yue Zhang, Makoto Mihara \& Chifumi Sato

The authors cannot guarantee the accuracy of the results and conclusions described in this article and wish to retract it. In addition, Hisashi Moriguchi's affiliation is incorrect. He is affiliated with University of Tokyo but not with Massachusetts General Hospital nor with Harvard Medical School. The study did not receive Institutional Review Board approval. 